\title{
CHANGES IN PRODUCTION MODES AND INTELLECTUAL RELATIONS IN MANAGING THE BEHAVIOR OF OIL AND GAS LABORS IN MUARA BADAK DISTRICT
}

\section{PERUBAHAN MODE PRODUKSI DAN RELASI INTELEKTUAL DALAM PENGATURAN PRILAKU BURUH MIGAS DI KECAMATAN MUARA BADAK}

\author{
Nalendro Priambodo ${ }^{1}$, Sri Murlianti ${ }^{2}$, Martinus Nanang ${ }^{3}$ \\ Universitas Mulawarman, Indonesia \\ Email Correspondence: alendra_pri@ymail.com
}

\begin{abstract}
:
This study aims to identify the pattern of changes in the mode of production of people who work as farmers and fishermen in Kutai Kartanegara Regency, especially Muara Badak District after the entry of the oil and gas industry in the region, and analyze how intellectual relations are in regulating the behavior of oil and gas workers along with the social, economic and political impacts. raised. This type of qualitative research uses the Grounded Theory approach. The results of this study indicate that changes in the way people produce from agriculture, plantations, and traditional fisheries in Muara Badak District have been accompanied by a mechanism for releasing social ties to land and sea through intermediary policies that are pro to the formation of industrial commodities for market interests and result in a decline in the domestic industry due to dependence. in the oil and gas industry. This dependence also gave birth to an intellectual layer and a working class that served the interests of the plantation, aquaculture and oil and gas-based industries. The process of its journey was accompanied by the emergence of various kinds of class conflicts, which gave rise to types of organic intellectuals who tried to fight back against the exploitation that occurred.
\end{abstract}

Keywords: Intellectual Relations, Production Mode, Regulation of Oil and Gas Workers Behavior

\begin{abstract}
ABSTRAK:
Penelitian ini bertujuan untuk mengindentifikasikan pola perubahan mode produksi masyarakat yang berprofesi sebagai petani dan nelayan di Kabupaten Kutai Kartanegara, khususnya Kecamatan Muara Badak setelah masuknya industri migas di wilayah tersebut dan menganalisis bagaimana relasi intelektual dalam pengaturan prilaku buruh migas beserta dampak sosial, ekonomi dan politik yang ditimbulkan. Jenis penelitian kualitatif dengan menggunakan pendekatan Grounded Theory. Hasil penelitian ini menunjukan bahwa perubahan cara masyarakat berproduksi dari pertanian, perkebunan dan perikanan tradisional di Kecamatan Muara Badak ikut dibarengi dengan mekanisme pelepasan ikatan sosial dengan tanah dan laut melalui perantara kebijakan yang pro terhadap pembentukan komoditas industri untuk kepentingan pasar serta mengakibatkan kemunduran industri domestik akibat ketergantungan pada industri migas. Ketergantungan ini juga melahirkan lapisan intelektual dan kelas buruh yang mengabdi pada kepentingan industri berbasis perkebunan, pertambakan dan migas. Dalam proses perjalalanannya juga dibarengi dengan kemunculan berbagai macam konflik kelas sehingga memunculkan jenis intelektual organik yang berusaha melakukan perlawanan balik terhadap eksploitasi yang terjadi.
\end{abstract}

Kata Kunci: Mode Produksi, Pengaturan Prilaku Buruh Migas, Relasi Intelektual,

Article Info

Received

Accepted

Published

DOI

\author{
January 2020 \\ Janaury 2020 \\ January 2020 \\ https://doi.org/10.30872/psd.v1i1.17
}

Copyright and License

Authors retain copyright and grant the journal right of first publication with the work simultaneously licensed under a Creative Commons Attribution 4.0 International License that allows others to share the work with an acknowledgment of the work's authorship and initial publication in this journal. 


\section{PENDAHULUAN}

Industri minyak dan gas dikategorikan menjadi salah satu kegiatan ekonomi utama yang dapat menopang perekonomian Kalimantan Timur. Data dari Badan Pusat Statistik Kalimantan Timur tahun 2013 menunjukan bahwa salah satu penopang utama perekonomian Kalimantan Timur adalah sektor migas dan tambang yang berkontribusi 50 persen dari Pendapatan Domestik Regional Bruto Kalimantan (BPS dalam MP3EI,2012:93). Kaltim juga di nobatkan sebagai salah satu daerah eksportir migas terbesar di Indonesia, pada tahun 2008-2013 Kaltim berkontribusi sebesar 37,56 persen hingga 45,081 persen dari total produksi gas alam nasional. Pada tahun 2015, Kaltim menyumbang 15,92 persen hingga 16,53 persen produksi minyak nasional (Tribun Kaltim, 14 April 2015)

Kalimantan Timur sejak lama menyimpan jejak ekploitasi migas dunia. Khususnya sejak penjajahan Belanda atas Kesultanan Kutai. Belanda berhasil memaksa Kesultanan Kutai untuk bertekuk lutut dan menjadikan seluruh daerah kesultanan Kutai sebagai onderafdeeling, atau wilayah kekuasaan Belanda. Bahkan dalam perjanjian tahun 1850 yang dibuat oleh Belanda atas Kesultanan Kutai, disebutkan bahwa wilayah yang di kuasai Sultan Kutai adalah pinjaman dari Belanda. Atas izin yang di keluarkan Sultan Kutai pada tahun 1888 kepada Jacobus Hubertus Manten, seorang investor minyak dari Belanda, untuk melakukan pencarian minyak di wilayah Kesultanan Kutai. Lima tahun berselang, tahun 1893 lapangan Sanga-Sanga mulai beroprasi yang di ikuti oleh pembangunan kilang minyak di Balikpapan tahun 1894 oleh perusahaan migas swasta asing bernama Shell. Maka di mulailah perjalanan Eksploitasi migas Pertama di Kalimantan Timur. (Syamtasiah, $2013: 105-130$ )

Sejarah panjang relasi dan masuknya modal asing skala besar berupa pembentukan industri migas di Indonesia khususnya Kalimantan Timur telah dicatat sebagai salah satu pertarungan panjang berbagai pihak dan kelas sosial di Indonesia. Pasca dekolonialisasi, dengan dukungan serikat-serikat buruh minyak, Soekarno menjalankan praktek Nasionalisasi aset-aset migas asing untuk kemudian dikontrol sendiri oleh bangsa Indonesia.

Kurang lebih setahun setelah di sahkanya Undang-Undang No 01 Tahun 1967 tentang Penanam Modal Asing, pada tanggal 8 Agustus 1968. Tokoh perminyakan dari Texas, Roy M. Huffington dan pengusaha asal Virginia, Jendral Arch Sproul, menandatangi kontrak bagi hasil dengan Pertamina yang meliputi areal seluas 631.000 Hektar di daerah Delta Sungai Mahakam yang kaya akan minyak dan gas. Kontrak pertama yang berlangsung selama 30 tahun di bawah bendera HUFFCO berakhir pada tanggal 7 Agustus 1998, dan kontrak kedua, selama 20 tahun dari tanggal 7 Agustus 1998 hingga 7 Agustus 2018.

Sebelum perusahaan masuk di daerah yang sekarang di kenal sebagai Kecamatan Muara Badak, penduduk yang mendiami lokasi tersebut sebagian besar adalah perantau dari Sulawesi Selatan dan Sulawesi Barat yang kemudian menggantungkan hidupnya sebagai nelayan, saudagar dan sebagian bertani. Masuknya investasi selalu dibarengi dengan janji yang disampaikan oleh Pemerintah, bahwa industri migas akan mensejahtrakan masyarakat lewat infrastruktur dan lapangan pekerjaan bagi masyarakat. 47 tahun sejak perusahaan ini masuk di Muara Badak, konflik antara petani, nelayan, buruh dengan pemerintah dan perusahaan datang silih berganti. Ledakan-ledakan konflik periodik yang kemudian terus berakumulasi hingga sekarang.

Tren ledakan konflik yang berkisar seputar sengketa tanah, pengangguran dan urusan ketenagakerjaan. Tercatat sejak tahun 1999-2001, ketika terjadi mogok besar yang dilakukan oleh buruh VICO menuntut masalah upah dan hak normatif lainya yang tidak dipenuhi perusahaan, walau mogok itu berhasil di redam hingga pembubaran Serikat Buruh Seluruh Indonesia (SBSI). Tampaknya aksi juga makin merambat ke sektor rakyat lainya, tahun 2013 warga dan pemuda lokal yang mengatasnamakan Persatuan Pemuda Pengangguran Muara Badak melakukan aksi besar menuntut VICO lebih banyak merekrut pekerja Lokal Yang terbaru adalah mogok buruh PT Karebet Mas Indonesia di April 2015 menuntut masalah upah dan status kerja.

Konflik yang kemudian bukan hanya berkaitan dengan perubahan cara masyarakat berproduksi, ketenagakerjaan, dan pertarungan perebutan ruang hidup, namun juga dalam momen tertentu berbarengan dengan produksi ilmu pengetahuan yang menjadi sarana bagi praktik kapitalisasi ruang yang didominasi abstraksi ekonomi dan pengaturan prilaku klas pekerja. Praktek kepengaturan yang kemudian dalam banyak literatur selalu dilakukan oleh intelektual sebagai perantara antar kelas

\subsection{Teori Mode Produksi Dengan Pendekatan Materialisme Dialektika Historis, Karl Marx}

Mode produksi merupakan pendekatan ekonomi-politik dalam melihat suatu masyarakat. Metode ini berangkat dari pengkajian sejarah manusia dan masyarakat sejak semula terbentuk. Marx bersama Engels menemukan bahwa perkembangan sejarah masyarakat didasari oleh faktor materil yaitu produksi (menghasilkan) sebagai sarana bertahan hidup sejak keberadaan masyarakat pertama. Mode produksi ini memiliki dua aspek yaitu force of production (tenaga produksi) dan relations of production (hubungan produksi) yang mana yang pertama menentukan (determinan) yang kedua. (PRP, tanpa tahun:1) 
Dalam mode produksi inilah terletaknya kontradiksi sebagai motor penggerak perubahan. Kontradiksi sebagai basis determinasi oleh faktor-faktor tenaga produksi, yang bukan hanya semata-mata bicara manusiamanusia (kelas pekerja) sebagai elemen satu-satunya. Terdapat elemen lain yang harus di analisa yakni alat produksi yang dipakai yaitu objek produksi dan perkakasnya..

\subsection{Pembentukan Tenaga Produksi}

Produksi pada dasarnya merupakan proses interaksi antara masyarakat dengan alam. Dalam proses interaksi tersebut, manusia mendapatkan, dari alam sekitarnya, sumber-sumber kehidupan yang dibutuhkan. Tahap-tahap evolusi manusia dan perkakas kerjanya terjadi sejalan dengan tahap-tahap proses pembentukan masyarakat manusia itu sendiri. Masyarakat tak bisa terbentuk sebelum manusia hadir, dan bentuk-bentuk hubungan baru di antara individu hanya bisa berkembang saat leluhur manusia telah menjadi komunitas.

Aktivitas kerja manusia berbeda dengan aktivitas kerja binatang yang paling berkembang sekalipun. Pertama, aktivitas kerja manusia menghasilkan suatu pengaruh aktif terhadap alam, sedangkan binatang hanya menyesuaikan diri pada alam; kedua, aktivitas kerja manusia mensyaratkan penggunaan secara sistematik (pada dasarnya penciptaan) perkakas produksi; ketiga, aktivitas kerja manusia memiliki maksud tertentu, merupakan suatu aktivitas yang sadar; keempat, aktivitas kerja manusia sejak awalnya bersifat sosial dan tak bisa dipahami tanpa masyarakatnya. (Lorimer, 2013 :127)

\subsection{Sasaran Kerja, Alat Kerja dan Tenaga Kerja}

Untuk memenuhi kebutuhan hidupnya manusia harus bekerja. Ada tiga elemen yang harus ada untuk bekerja. Elemen tersebut adalah:

a. Sasaran kerja: bahan mentah yang secara langsung atau tidak langsung dihasilkan oleh alam

b. Alat kerja: alat produksi yang diciptakan manusia sesuai dengan tingkat perkembangan masyarakatnya

c. Tenaga kerja: yaitu sang produsen, manusia itu sendiri

\subsection{Hubungan Produksi}

Relasi sosial dalam sebuah produksi berjalan dalam ragam bentuk seiring dengan karakter dan perkembangan dari alat produksi. (Marx,1958:28). Secara umum, hubungan produksi yang ada sesuai dengan derajat perkembangan tenaga produktif yang ada, dengan kecanggihan (jumlah) alat produksi yang ada, serta dengan teknik dan organisasi kerja yang ada.Totalitas dari relasi sosial produksi inilah yang membentuk sistem kehidupan masyarakat yang berbeda-beda dalam setiap potongan sejarah kehidupan umat manusia. Perkembangan dari materialitas alat produksi menjadikan relasi sosial produksi memiliki karakter yang berbeda dan spesifik di dalam setiap fase perkembangan sejarah masyarakat.

\subsection{Basis Material dan Suprastruktur}

Setiap masyarakat manusia harus berproduksi untuk bertahan hidup. Materialisme historis menyatakan bahwa jalan dimana umat manusia mengorganisir produksi materialnya menyusun basis dari semua organisasi sosial. Basis tersebut kemudian menentukan semua aktivitas sosial lainnya administrasi hubungan antara kelompok-kelompok manusia (terutama sekali kemunculan dan perkembangan negara), produksi spiritual, moral, hukum, agama, dsb. Apa yang disebut dengan aktivitas suprastruktur sosial tersebut selalu tetap terhubung, dengan satu jalan atau yang lainnya, pada basis. Sedangkan fungsi dari suprastruktur adalah untuk melindungi, membentengi dan mengembangkan basisnya. Materialisme historis tidaklah menegaskan bahwa produksi material (faktor ekonomi) secara langsung dan segera menentukan isi dan bentuk dari semua yang disebut dengan aktivitas suprastruktur. Lebih dari itu, basis sosial bukan sesederhana aktivitas produksi begitu saja, dan bukan juga "produksi material" dilihat dalam kondisi terisolasi. Adalah hubungan sosial yang dibentuk oleh manusia dalam produksi kehidupan material mereka. Sesungguhnya, materialisme historis bukanlah, oleh karena itu, determinisme ekonomi tetapi determinisme sosio-ekonomi. 


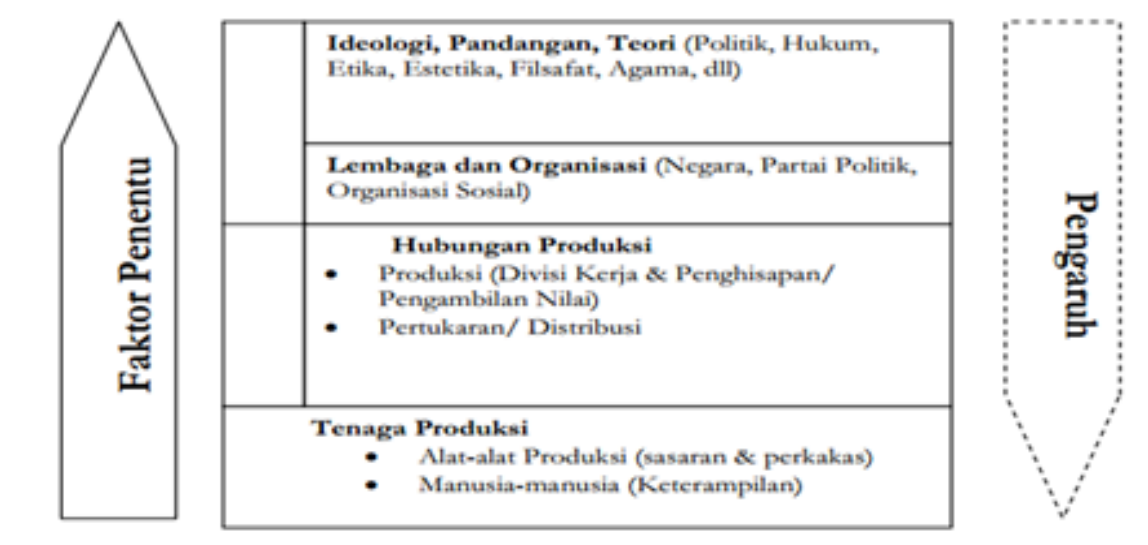

Figure 1 Basis Material dan Suprastruktur

Sumber : (KPO-PRP 2011:4)

\subsection{Intelektual dan Proses Pembentukanya}

Mengikuti pendapat Eyerman (Eyerman dalam Dhakidae, 1994:21) definisi intelektual bisa di kategorikan dalam 2 kategori. Pertama, definisi yang menginterpretasikan intelektual dalam kerangka karakteristik-karakteristik personal, seperti "seseorang yang menjadikan berfikir sekaligus bekerja dan bermain (Lasch dalam Dhakidae, 1998:21). Kedua, definisi yang mengaitkan dengan struktur dan fungsi sosial tertentu. Definisi ini diajukan, misalnya oleh Seymour Martin Lipset yang mendefiniskan para intelektual sebagai mereka "yang menciptakan, menyebarluaskan serta menjalankan kebudayaan". (Dhakidae, 1998:22)

Sedangkan menurut Gramsci "Kaum intelektual sebagai sebuah kelas independen yang terpisah dari kategori sosial adalah sebuah mitos. Semua manusia berpotensi untuk menjadi intelektual, sesuai dengan kecerdasan yang dimiliki, dan dalam cara menggunakanya. Tapi tidak semua orang intelektual dalam makna fungsi sosial. Dimana dalam makna fungsionalnya kaum intelektual terbagi dalam dua kelompok. Pada kelompok pertama terdapat kaum intelektual profesional "tradisional", kaum pujangga, ilmuan dan sebagainya yang memiliki posisi dalam celah masyarakat yang mempunyai aura antra kelas tertentu, tetapi berasal dari hubungan kelas masa silam dan sekarang melingkupi pembentukan kelas historis. Yang kedua, terdapat kaum intelektual "organik", unsur pemikir dan pengorganisasian dari sebuah kelas sosial fundamental tertentu. Kaum intelektual organik ini dapat dengan mudah di bedakan melalui profesi mereka, yang mungkin dapat terjadi karakteristik pekerjaan kelas mereka, bukan melalui fungsi mereka dalam mengarahkan gagasan aspirasi kelas organik mereka. (Gramsci,2013:3).

Di dunia moderen, pendidikan teknis yang terikat erat dengan pekerja industri bahkan pada tingkat primitif dan kualitatif sekalipun, dimana tiap-tiap klas harus membentuk basis untuk jenis baru intelektual. Sehingga sekolah adalah instrumen tempat intelektual dari berbagai tingkatan dielaborasikan. Lebih jauh lagi, Gramsci kemudian membuat perbedaan posisi antara intelektual kota dan desa. Menurutnya "kaum intelektual telah berkembang seiring dengan perkembangan industri dan ini terkait dengan prihal keuntungan dari sebuah industri. Kaum intelektual kota tidak mempunyai inisiatif otonomis untuk menjelaskan rencana pembangunan. Pekerjaan mereka akan mengartikulasikan hubungan antara kapitalis dengan massa, dan melaksanakan eksekusi atas rencana produksi yang diputuskan oleh staf umum industri, yang mengendalikan tahap tahap dasar pekerjaan. Secara keseluruhan, intelektual kota sudah sangat distandarkan, intelektual kota yang tinggi lebih mudah di identifikasikan dengan staf umum industri atau posisi vital dalam sebuah institusi”. (Gramsci, 2013:20)

Sedangkan intelektual desa sebagaian besar adalah jenis "tradisonal" yakni mereka yang terhubung dengan massa sosial dari masyarakat pedesaan dan borjuis kecil di kota, utamanya kota kota kecil. Tapi belum dielaborasikan dan digerakan oleh sistem kapitalis. Jenis intelektual ini berhubungan dengan massa petani dan administrasi lokal dan wilayah (pengacara, notaris dan sebagainya). Karena aktivitas ini, mereka mempunyai fungsi politik sosial yang penting, karena mediasi profesional sulit dipisahkan dari fungsi politik". (Gramsci,2013:20)

Menurut (Patria\&Arif,2003:121)“Hegemoni adalah sebuah rantai kemenangan yang didapat melalui mekanisme konsensus ketimbang melalui penindasan terhadap kelas sosial lainya. Ada berbagai cara yang digunakan, misalnya melalui institusi yang ada dalam masyarakat yang menentukan secara langsung atau tidak langsung struktur kognitif dari masyarakat. Karena itu hegemoni pada hakekatnya adalah upaya untuk menggiring orang agar menilai dan memandang probematika dalam kerangka yang ditentukan" 
Teori hegemoni, di dasarkan pada konsep bahwa suatu ilmu pengetahuan atau ideologi atau keyakinan baru dimasukan secara terselubung, pembiasaan maupun dengan jalan indoktrinasi dan pemaksaan ke dalam atmosfer kesadaran kolektif massa yang memunculkan kesadaran kolektif baru. Sumber pengetahuan yang dimiliki individu dalam suatu kelompok, tidak selalu mudah ditebak asalnya, bisa jadi kesadaran dan pengetahuan yang selama ini mengendap dalam masyarakat merupakan suatu program "hegemonik" yang ditanamkan subjek kelompok tertentu. (Patria \& Arif, 2003:122)

Bagi Gramsci, hegemoni melalui konsensus muncul melalui komitmen aktif atas kelas sosial yang secara historis lahir dalam hubungan produksi. Menurut (Gramsci, 2006:47) "Secara tidak langsung konsensus sebagai sebuah komitmen aktif yang di dasarkan pada adanya pandangan bahwa posisi tinggi yang ada adalah sah dan memiliki legitimasi. Ada dua hal dasar yang menjadi penyebab munculnya kesadaran ini, yakni pendidikan dan mekanisme kelembagaan. Bagi Gramsci pendidikan dalam kapitalisme tidak pernah menyediakan kemungkinan kesadaran kritis dan sistematis bagi buruh. Mekanisme kelembagaan (Gereja, sekolah, partai politik, media massa dsb) menjadi tangan tangan atau agen - agen kelas yang berkuasa untuk menentukan ideologi yang mendominir. Bahasa dan ilmu pengetahuan menjadi sarana yang penting untuk melayani kepentingan hegemonik tadi sesuai dengan sistem yang di kehendaki. Oleh karena itu pembangunan pembangunan ilmu yang integral dengan massa menjadi sangat penting. Karena pengalaman Kapitalisme yang berhasil mengukuhkan dominasi kesadaranya juga tidak lepas dari peran intelektual organik dalam klas borjuis itu sendiri. Satus hegemonik sebuah gagasan akan ditentukan oleh kolaborasinya dengan kekuatan ekonomi politik yang material. Gramsci tidak melulu hanya membicarakan bagaimana kelas berkuasa membangun hegemoninya, namun juga penekan terhadap gerakan rakyat dalam upaya membangun posisi hegemoniknya di tengah situasi kapitalisme.

Hegemoni perlu difahami sebagai sebuah cara atau strategi untuk melegitimasi kekuasaan material (power and material force) yang sudah dibangun. Sehingga, bukan hanya gagasan yang menentukan, tetapi basis material apa yang menyebabkan gagasan tersebut bisa bertahan. Dalam perspektif ini, kita dapat melihat bahwa hegemoni adalah cara peneguhan kekuasaan setelah menguasi basis produksi. Maka intelektual organik bisa kita fahami sebagai intelektual yang merepresentasikan kelompok sosial tertentu dalam relasi produksi yang ada dalam masyarakat, dan membawa gagasan-gagasan untuk membuat tatanan yang ia bentuk bisa bertahan secara hegemonik.

\section{METODE}

Penelitian ini merupakan jenis penelitian kualitatif dengan menggunakan metode pendekatan Grounded Theory. Sesuai dengan nama yang disandangnya, tujuan dari Grounded Theory Approach adalah teoritisasi data. Teoritisasi adalah sebuah metode penyusunan teori yang berorientasi tindakan/interaksi, karena itu cocok digunakan untuk penelitian terhadap perilaku.

\subsection{Lokasi Penelitian1}

Penentuan lokasi dan setting penelitian selain dibingkai dalam kerangka teoritis juga dilandasi oleh pertimbangan teknis oprasional. Untuk itu, lokasi dan setting penelitian dipertimbangkan berdasakan kemungkinan dari masalah yang hendak kaji secara mendalam, hal ini penting karena betapa menariknya suatu kejadian fenomena, tetapi jika sulit dimasuki lebih dalam oleh peneliti, maka akan menjadi kerja yang sia-sia. Selanjutnya penting juga dipertimbangkan apakah lokasi dan setting aktor dalam penelitian memberi peluang yang menguntungkan untuk di kaji, seperti serikat buruh, organisasi, kegiatan, interaksi sosial yang ada, serta struktur sosial yang mungkin untuk di dekati. Dengan memperhatikan faktor faktor tersebut, maka kemudian penulis menetapkan bahwa lokasi peneliatian adalah Kecamatan Muara Badak, Kabupaten Kutai Kartanegara, yang terbagi menjadi 13 Desa. Penulis kemudian menetapkan beberapa desa yang di jadikan lokasi penelitian antara lain, Desa Muara Badak Ulu dan Muara Badak Ilir sebagai desa pertama yang lahir dan menjadi pintu masuk utama masuknya industri migas. Sedangkan untuk menggambarkan bagaimana peran industri migas, pertambakan dan industri perkebunan sawit dalam proses mengubah pola pertanian dan perikanan tangkap penduduk lokal, penulis menetapkan desa Saliki, Gas Alam dan Tanjung Limau sebagai lokasi penelitian. Kemudian, untuk menggambarkan bagaimana kepengaturan prilaku buruh migas terjadi, penulis menetapkan desa Badak Baru, dan Gas Alam, karena pertimbangan di desa ini terdapat mayoritas pemukiman dan pusat perlawanan buruh migas di Kecamatan Muara Badak

\subsection{Fokus Penelitian}

1. Bagaimana Industri migas berperan dalam perubahan mode produksi serta perannya dalam proses pembentukan kelas pekerja di Kecamatan Muara Badak menggunakan parameter mode produksi yaitu. 
a.Sasaran kerja, alat kerja dan tenaga kerja. Dimana kemudian penulis menggunakan ketiga parameter di atas untuk melihat bagaimana Industri migas berperan dalam perubahan ketiga aspek tersebut dalam rentan waktu 1806-2015 di Kecamatan Muara Badak.

2. Bagaimana relasi intelektual berperan dalam pengaturan prilaku klas pekerja di Kecamatan Muara Badak.

a. Relasi antara Intelektual dengan lembaga pemerintahan, serikat buruh, perusahaan dan masyarakat.

b.Metode - metode yang digunakan untuk mengarahkan prilaku kelas pekerja

c.Medium apa yang digunakan untuk mengatur prilaku klas pekerja (Undang - undang, Peraturan atau artefak yang digunakan)

3. Dampak-dampak ekonomi, politik dan sosial apa yang ditimbulkan akibat perubahan mode produksi dan pengaturan prilaku klas pekerja di Kecamatan Muara Badak.

\subsection{Sumber dan Metode Pengumpulan Data}

Pengumpulan data dalam penelitian ini diperoleh dengan cara :

a. Wawancara mendalam (indepth interview) yakni teknik pengumpulan data dengan cara berkomunikasi langsung dengan informan yang menguasai isu berkaitan dengan fokus penelitian. Informan kunci yang diwawancarai dalam penelitian ini adalah Ketua APDESI (Asosiasi Perangkat Desa Seluruh Indonesia) Kecamatan Muara Badak sekaligus juga sebagai Kepala Desa Gas Alam yaitu H. Dayat, Pak Sunan Rimba selaku ketua KOBRA (Komando Bela Negara) Kecamatan Muara Badak sebagai pelaku langsung yang terlibat dalam proses perekrutan buruh untuk subkontraktor VICO dan jual jual beli lahan sejak VICO pertama kali berdiri di tahun 19682015 di Kecamatan Muara Badak. Tokoh di luar Muara Badak yang dijadikan sebagai informan adalah Merah Johansyah Ismail selaku Dinamisator Jatam Kaltim, Carolus Tuah selaku Direktur Pokja 30 dan Herdiansyah Hamzah selaku akademisi dan Anggota Dewan Pengupahan Provinsi Kaltim. Rudi Irawan selaku ketua Persatuan Pemuda Muara Badak, Sapri Maulana selaku kordinator Serikat Buruh Kontraktor VICO Indonesia

b. Studi kepustakaan, yakni teknik pengumpulan data dengan cara menelusuri dan mengkaji bahanbahan yang sesuai dengan kebutuhan penelitian seperti buku, jurnal, makalah dan artikel berkaitan dengan fokus penelitian.

c. Pengamatan lapangan melalui observasi, wawancara dan dokumentasi

\subsection{Analisis Data}

1. Tahap Pengumpulan data yaitu Proses memasuki lingkungan penelitian dan melakukan pengumpulan data penelitian.

2. Tahap Reduksi Data yaitu Proses pemilihan, pemusatan perhatian pada penyerderhanaan, pengabstrakan, dan transformasi data kasar yang muncul dari catatan-catatan tertulis dari lapangan.

3. Tahap Penyajian Data yaitu Penyajian informasi untuk memberikan kemungkinan adanya penarikan kesimpulan dan pengambilan.

4. Tahap Penarikan Kesimpulan/Verifikasi yaitu Penarikan kesimpulan

\subsection{Uji Keabsahan Data}

Triangulasi Pengujian keabsahan data yang dilakukan oleh peneliti adalah dengan menggunakan teknik triangulasi yaitu teknik pemeriksaan data yang memanfaatkan sesuatu yang lain di luar data itu untuk pembanding terhadap data yang didapat dari teknik observasi. Teknik triangulasi yang digunakan dalam penelitian ini adalah triangulasi dengan sumber artinya peneliti membandingkan data dari hasil observasi dengan data hasil wawancara yang ditunjang oleh data studi dokumentasi. Data yang diperoleh melalui observasi dikumpulkan, dipelajari dan diambil kesimpulan sementara kemudian dibandingkan dan dilakukan cek silang dengan hasil wawancara yang diperoleh dari para responden. Data yang diperoleh melalui observasi juga dibandingkan dan dicek silang dengan hasil dokumentasi yang diperoleh. Demikian pula hasil wawancara dengan para informan dibandingkan dan dicek silang dengan hasil dokumentasi sehingga dapat diambil kesimpulan secara keseluruhan dengan teliti dan seksama sehingga validitas penelitian dapat dipertanggung jawabkan. Dengan demikian derajat kepercayaan informasi yang didapat dalam penelitian ini terjamin karena hasil penelitian merupakan deskripsi hasil observasi, wawancara, dan dokumentasi.

\section{HASIL DAN PEMBAHASAN}

Kebanyakan negara-negara kaya sumberdaya alam yang mendapatkan pengalaman dengan merosotnya sektor-sektor ekonomi domestik, disebut terperangkap dalam situasi "Dutch Disease" yakni sebuah kondisi merujuk ketika Belanda menemukan gas alam di laut utara pada tahun 1970-an, Belanda tiba-tiba menyadari bahwa sektor manufaktur mereka tiba-tiba berkinerja lebih buruk dari yang mereka perkirakan. Kondisi ini 
terjadi akibat peningkatan mendadak nilai ekspor sumberdaya alam yang ternyata menghasilkan apresiasi nilai langsung terhadap nilai kurs riil. Ini mengakibatkan ekspor komoditas non sumberdaya alam berada dalam posisi sulit dalam kompetisi dengan impor beragam komoditas menjadi hampir mustahil (Humphreys, 2007:6 dan lihat juga Glyafson, 2001:4)

Sebagai perbandingan bisa kita menengok ratus tahun lalu ketika Belanda berhasil mendorong perubahan struktur perekonomian kerajaan di wilayah Kalimantan Timur yang dalam perjalanannya berkembang menjadi Kalimantan Utara, dimana Kerajaan Kutai memainkan peran besar didalamnya. Terlihat bahwa pembentukan industri migas yang berkembang di wilayah Kerajaan Kutai sejak 1905 telah mendorong perubahan produksi domestik untuk kepentingan ekspor, sekaligus menurunkan produktivitas komoditas lokal lain, seperti pada tabel dibawah ini.

Tabel 1. Jumlah Nilai Komoditas Ekspor Kalimantan Timur Selama Kurun Waktu 1900-1938

\begin{tabular}{|c|c|c|c|c|c|c|}
\hline Jenis Komoditas & $1900(\%)$ & $1905(\%)$ & $1910(\%)$ & $1920(\%)$ & $1930(\%)$ & $1938(\%)$ \\
\hline Getah perca & 61.9 & 32,6 & 15,3 & 2,4 & 1,2 & 1,3 \\
\hline raton & 7.7 & $9 ., 7$ & 4,9 & 0,8 & 1,6 & 0,8 \\
\hline kayu & & & 0,1 & 0,1 & 0,2 & 0,8 \\
\hline $\begin{array}{l}\text { Kelebihan produksi } \\
\text { hutan }\end{array}$ & & 7,9 & 13,9 & 0,5 & 0,3 & 0,8 \\
\hline karet & & & 0,2 & 6,8 & 10,2 & 17,0 \\
\hline lada & 0,9 & 2,5 & 4,7 & 0,3 & 1,6 & 0,4 \\
\hline tembakau & 23,7 & & & & & \\
\hline Batu bara & & 3,4 & 3,8 & 0,5 & 2,9 & 1,5 \\
\hline Minyak mentah & & 34,5 & 21,1 & 31,6 & 27,4 & 16,8 \\
\hline kerosine & & & & 11,6 & 15,7 & 7,1 \\
\hline $\begin{array}{l}\text { Minyang yang telah } \\
\text { disuling }\end{array}$ & & 3,5 & 24,7 & 44,4 & 35,7 & 50,8 \\
\hline \multirow{2}{*}{$\begin{array}{l}\text { Kelebihan produksi } \\
\text { minyak }\end{array}$} & 5,8 & 5,9 & 11,3 & 1,0 & 3,2 & 3,2 \\
\hline & 100 & 100 & 100 & 100 & 100 & 100 \\
\hline $\begin{array}{l}\text { Nilai total produksi } \\
\text { dalam } f \text { (Guider) }\end{array}$ & 1.459 .079 & 12.989.158 & 21.928.306 & 210.839 .748 & 97.287 .748 & 71.046 .673 \\
\hline
\end{tabular}

Sumber: Thomas Lindblad, Westersen niet-westers Economisch Gedrag in Zuid-Oost Kalimantan 1900-1940 dalam Bijdragen tot de Taal Land en Volkenkunde 142 (1986). No. 2/3. Leiden.

Sementara itu, 113 tahun semenjak insinyur perminyakan Belanda J.H Manten pertama kali melakukan pengeboran minyak di wilayah Kesultanan Kutai yang sekarang berubah menjadi Kabupaten Kutai Kartanegara, tampaknya wabah "Dutch Disease" masih menghantui salah satu Kabupaten terkaya di Indonesia yakni Kutai Kartanegara. Kondisi ini tercermin dalam perbandingan postur Pendapatan Domestik Regional Bruto (PDRB) Kabupaten Kutai Kartanegara dan distribusi Pendapatan Domestik Regional Brutto dengan migas di Kecamatan Muara Badak. Pada tabel dibawah ini :

Tabel. 2. Produk Domestik Regional Bruto (PDRB) Kabupaten Kutai Kartanegara Dengan Minyak Dan Gas Bumi Atas Dasar Harga Berlaku Menurut Lapangan Usaha (juta rupiah) 2000-2013

\begin{tabular}{llll}
\hline Sektor ekonomi & $\mathbf{2 0 0 0}$ & $\mathbf{2 0 1 0}$ & $\mathbf{2 0 1 3}$ \\
\hline pertanian & 1.930 .664 & 6.444 .519 & 9.5888 .289 \\
Pertambangan dan penggalian & 19.450 .109 & 84.313 .364 & 104.994 .176 \\
Industri pengolahan & 445.377 & 1.260 .109 & 1.771 .857 \\
Listrik gas dan air minum & 11.852 & 50.474 & 85.392 \\
Bangunan dan konstruksi & 512.650 & 3.175 .242 & 5.303 .868 \\
Perdagangan, restoran dan hotel & 568.314 & 2.823 .709 & 4.615 .374 \\
pengangkutan dan komunikasi & 116.979 & 425.106 & 673.897 \\
Keuangan, persewaan dan jasa & 159.11 & 375.106 & 673.897 \\
perusahaan & & & \\
Jasa jasa & 209.453 & 1.597 .455 & 2.287 .039 \\
\hline Totak PDRB (triliun Rupiah) & $\mathbf{2 3 . 4 0 4 . 5 0 9}$ & $\mathbf{1 0 0 . 4 6 5 . 0 5 0}$ & $\mathbf{1 2 3 . 9 5 9 . 6 8 1}$ \\
\hline
\end{tabular}

Sumber : Kutai Kartanegara dalam angka tahun 2000,2010 dan 2014 
Tabel 3. Distribusi PDRB Dengan Migas Kecamatan Muara Badak Tahun 2010 (Persen)

\begin{tabular}{lc}
\hline \multicolumn{1}{c}{ Sektor Ekonomi } & Prosentase \% \\
\hline Pertanian & 1.5 \\
Pertambangan dan penggalian & 95.96 \\
Industri Pengolahan & 0.03 \\
Bangunan & 1.14 \\
Perdagangan, Hotel dan Restoran & 0.45 \\
Lainnya & 0.91 \\
Total & 100 \\
\hline
\end{tabular}

Jika dalam kasus seperti Belanda yang telah membangun industri dan manufaktur sejak abad ke-19, 'dutch disease' mengakibatkan penurunan produksi manufakturnya. Sedangkan di negara berkembang yang industrialisasinya lemah seperti Indonesia, khususnya Kecamatan Muara Badak di Kabupaten Kutai Kartanegara, kelihatanya yang dirugikan atau gagal terbangun adalah sektor pertanian, industri pengolahan dan manufaktur yang diharapkan mampu menyerap banyak tenaga kerja sehingga mampu menggerakan motor perekonomian suatu wilayah di masa datang, setelah sumberdaya alam sudah tidak sanggup lagi menjadi sumber pendapatan di masa mendatang. Kondisi yang terjadi sekarang di Kutai Kartanegara dan Kecamatan Muara Badak juga mirip seperti yang terjadi di Australia pada abad ke 19 ketika demam penggalian emas berlangsung atau juga ketika perampokan emas dan perak di Amerika Latin pada abad ke 16 oleh dua negeri Imperialis, Spanyol dan Portugis.

Mudah saja untuk melihat bias menyangkut sifat dasar sumber kemakmuran dari prediksi diatas, ketika kemakmuran suatu negara atau wilayah administratif dibawahnya bergantung pada investasi di bidang manufaktur atau kegiatan produktif lainya, maka investasi sumberdaya manusia adalah bagian terpenting dalam penciptaan kemakmuran ini. Sebaliknya, ketika kemakmuran suatu negara diperoleh dari kelimpahan sumberdaya alam, maka investasi untuk tenaga kerja terampil tidak diperlukan untuk merealisasikan pendapatan yang sedang berjalan. Tanpa fokus pada penciptaan kemakmuran, atau keberlanjutan, maka investasi pada sumberdaya manusia (atau investasi produktif lainya) jelas akan kurang diperhatikan.

Menurut (Gylafson,2001:10) Industri berbasis sumberdaya alam dalam banyak contoh hanya membutuhkan tenaga kerja dengan skill/kemampuan yang rendah dan mungkin juga hanya memberikan sedikit tambahan modal yang intensif terhadap industri lainya, dengan demikian hanya memberikan sedikit manfaat dan keuntungan eksternal terhadap industri lainya. Selain itu, para buruh yang terlepas dari aktivitas produksi lainya seperti pertanian, perikanan, kehutanan dan pertambangan umumnya relatif kecil untuk dapat terserap dan membangun industri lainya, walaupun ada pengecualian terhadap model industri pertanian moderen dan industri pengeboran migas dengan teknologi tinggi yang tentunya membutuhkan kualifikasi tenaga kerja dengan skill tinggi pula.

Ketertinggalan, perbedaan kualitas lulusan dan penciptaan penemuan baru dibidang rekayasa industri ditambah dengan tidak selarasnya pendidikan dengan jalur ekonomi utama turut membentuk lapisan tenaga kerja dengan skill rendah yang tidak mampu terserap dalam aktifitas produksi utama. Sementara terlepasnya masyarakat dari aktivitas pertanian dan perikanan di Muara Badak akibat munculnya industri migas dan perikanan komersial turut menambah limpahan tenaga kerja yang pada akhirnya saling bersaing satu sama lain dalam pasar kerja. Kondisi ini menimbulkan lemahnya daya saing pekerja dalam hubungan industrial.

\section{KESIMPULAN}

Industri berbasis sumberdaya alam dalam banyak contoh hanya membutuhkan tenaga kerja dengan skill/kemampuan yang rendah dan mungkin juga hanya memberikan sedikit tambahan modal yang intensif terhadap industri lainya, dengan demikian hanya memberikan sedikit manfaat dan keuntungan eksternal terhadap industri lainya Selain itu, para buruh yang terlepas dari aktivitas produksi lainya seperti pertanian, perikanan, kehutanan dan pertambangan umumnya relatif kecil untuk dapat terserap dan membangun industri lainya, walaupun ada pengecualian terhadap model industri pertanian moderen dan industri pengeboran migas dengan teknologi tinggi yang tentunya membutuhkan kualifikasi tenaga kerja dengan skill tinggi pula. 


\section{DAFTAR PUSTAKA}

Dhakidae, Dhaniel.1998. Cendekiawan Dan Kekuasaan Dalam Negara Orde Baru.Jakarta: Gramedia Pustaka Utama

Gramsci, Antonio, 2013. Prison Notebook: Catatan - Catatan Dari Penjara. Yogyakarta: Pustaka Pelajar

Humphreys, Macaratan dkk (ed) (2007) Escaping the Resource Course (P. A Rahmanto.Terjemahan) Samdhana Institute.Buku asli diterbitkan di New York tahun 2007: Columbia University Pres

Bogor:

Kementrian Kordinator Bidang Perekonomian, 2011, Masterplan Percepatan Percepatan Pertumbuhan Ekonomi Indonesia.

Kongres Politik Organisasi Perjuangan Rakyat Pekerja,2011, Pengantar Ekonomi Politik Marxist. Jakarta. Komite Sentral KPO-PRP

Lindblad Thomas, Westersen niet-westers Economisch Gedrag in Zuid-Oost Kalimantan1900-1940 dalam Bijdragen tot de Taal Land en Volkenkunde 142 (1986). No. 2/3. Leiden.

Lorimer, Doug, 2013. Pokok - Pokok Materialisme Historis: Pandangan Marxist Terhadap Sejarah dan Politik. Yogyakarta: Bintang Nusantara

Marx, Karl 2005, Kapital Volume I. Sebuah Kritik Ekonomi Politik, Proses Produksi Kapitalis Secara Menyeluruh. Jakarta: Hasta Mitra

2006, Kapital Volume II. Proses Sirkulasi Kapital. Jakarta: Hasta Mitra

,2007, Kapital Volume III. Proses Produksi Kapitalis Secara Menyeluruh. Jakarta: Hasta Mitra

Patria, Nezar dan Andi Arif, 2003. Antonio Gramsci: Negara \& Hegemoni, Yogyakarta: Pustaka Pelajar

Syamtasiah A. Ita, 2003 Kesultanan Kutai 1825 - 1910. Perubahan Politik dan Ekonomi Akibat Penetrasi Kekuasaan Belanda. Tangerang: Serat Alam Media

Badan Pusat Statistik Kutai dan Badan Perencanaan Pembangunan Daerah Angka 1998. Kutai : BPS dan BAPPEDA Kutai

Badan Pusat Statistik Kutai Kartanegara (2011) Kecamatan Muara Badak Kartanegara : BPS dan BAPPEDA Kutai Kartanegara (2013) Kecamatan Muara Badak Dalam Angka 2012.Kutai Kartanegara

, (2013)Kecamatan Muara Badak Dalam Angka 2013.Kutai Kartanegara : $\quad$ Badan Pusat Statistik Kutai Kartanegara

(2014) Kecamatan Muara Badak Dalam Angka 2014. Kutai Kartanegara : Badan Pusat Statistik Kutai Kartanegara

,(2015)Kecamatan Muara Badak Dalam Angka 2015. Kutai Kartanegara : Butan Put Bat Kartanegara

Pemerintah Kabupaten Kutai Kartanegara Peraturan Daerah No 17 Tahun 2010 Tentang Rencana Pembangunan Jangka PanjangDaerah (RPJPD) Kabupaten Kutai Kartanegara 2005-2025.

Dirjen Minyak dan Gas Bumi Indonesia Laporan Produktivitas Minyak dan Gas Indonesia 1970-1980. 